\title{
Psikologis Tokoh Utama dan Nilai Religius Novel Bidadari Bermata Bening Karya Habiburahman El-Shirazy
}

\author{
Harti \\ Universitas Indraprasta PGRI \\ Jalan Nangka No. 58 C/TB. Simatupang, Tanjung Barat, Jakarta Selatan 12530 \\ Hartyfadila@gmail.com
}

\begin{abstract}
Abstract The purpose of this research is to analyze the psychological main character and religious values in the novel Angel of Bening Edged by Habiburahman El-Shirazy to reveal the psychology of the main character and religious values. The method used in this research is to use a qualitative descriptive method by analyzing content. There are 291 information or findings in the main character's psychological and religious values. Information that shows Id as many as 43 citations at 39\%, ego elements as much as 36 quotations at 33\%, and super ego elements as much as 30 quotations at $28 \%$. Whereas the highest religious nilia is sharia. Information or findings that indicate the elements of faith as much as 57 citations at 31\%, as many as 61 citations as much as $34 \%$, and the Islamic elements as much as 64 quotations by $35 \%$.
\end{abstract}

Keywords: Psychological Main Figure, Religious Values, novel

\begin{abstract}
Abstrak
Tujuan penelitian adalah untuk menganalisis psikologis tokoh utama dan nilai religius dalam novel Bidadari Bermata Bening Karya Habiburahman El-Shirazy untuk mengungkapkan psikologis tokoh utama dan nilai religius. Metode yang digunakan dalam penelitian ini adalah menggunakan metode deskriptif kualitatif dengan cara menganalisis isi. Terdapat 291 informasi atau temuan dalam psikologis tokoh utama dan nilai religius. Informasi yang menunjukkan Id sebanyak 43 kutipan sebesar $39 \%$, unsur ego sebanyak 36 kutipan sebesar $33 \%$, dan unsur super ego sebanyak 30 kutipan sebesar $28 \%$. Sedangkan nilai religius yang paling tinggi adalah syariah. Informasi atau temuan yang menunjukkan unsur akidah sebanyak 57 kutipan sebesar $31 \%$, unsur akhlak sebanyak 61 kutipan sebesar 34\%, dan unsur Syariah sebanyak 64 kutipan sebesar 35\%.
\end{abstract}

Kata Kunci: Psikologis Tokoh Utama, Nilai Religius, novel

\section{PENDAHULUAN}

Novel merupakan salah satu bentuk karya sastra. Nurgiyantoro (2010) menjelaskan bahwa novel berasal dari kata "novella". Secara harfiah, novella berarti sebuah barang baru yang kecil, yang kemudian diartikan secara pendek yang berbentuk prosa. Dikatakan baru karena novel muncul kemudian setelah karya sastra lainnya, yakni puisi dan drama.

Sumardjo dan Saini (1998) menjelaskan bahwa novel merupakan bentuk karya sastra yang paling popular di dunia. Bentuk sastra ini paling banyak beredar, lantaran daya komunikasinya yang sangat luas pada masyarakat. Selain itu, novel merupakan karya imajinatif yang mampu membawa perasaan pembaca, baik menjadi senang, sedih, gundah, dan lain-lain. 
Dalam sebuah novel, seringkali dipaparkan peristiwa yang terjadi di masyarakat. Peristiwa-peristiwa tersebut dikemas dalam bentuk yang lebih menarik sehingga khalayak dapat memahami kejadian tersebut dari sisi penulis. Peristiwaperistiwa yang diangkat oleh penulis ke dalam novel biasanya berasal dari peristiwa yang besar. Peristiwa-peristiwa besar itu adalah peristiwa yang banyak disoroti masyarakat, seperti perjalanan hidup, percintaan, bahkan yang tidak kalah penting adalah peristiwa yang berhubungan dengan kereligiusan seorang tokoh yang terjadi pada masyarakat. Sebagian ahli sastra beranggapan bahwa novel dapat dikatakan baik, apabila di dalamnya terdapat konflik.

Konflik yang dihadirkan oleh seorang pengarang tidak luput dari kenyataan bahwa keberadaannya merupakan bagian dari kehidupan manusia. Sebagai makhluk sosial yang hidup berdampingan, sering kali timbul adanya konflik. Timbulnya suatu konflik dapat dipicu oleh beragam motif. Salah satu motif yang memicu adanya suatu konflik pada manusia sebagai makhluk sosial.

Sastra dapat dipandang sebagai suatu gejala sosial, sastra yang ditulis oleh pengarang pada suatu kurun waktu tertentu, pada umumnya langsung berkaitan. Dalam sastra diartikan bahwa konflik merupakan ketegangan atau pertentangan di dalam cerita rekaan atau drama yakni pertentangan antara dua kekuatan, pertentangan dalam diri satu tokoh, pertentangan antara dua tokoh, dan sebagainya (Sari, 2013).

Daya tarik religius dalam karya sastra merupakan hal yang sangat penting. Aspek religius tergambar dalam tingkah laku diri masing-masing tokoh. Terutama dalam menghadapi konflik-konflik yang terdapat dalam sebuah cerita. Aspek yang dimiliki oleh seseorang tokoh bisa menjadi sebuah penentu diri tokoh dalam mengambil tindakan ataupun keputusan yang akan diambilnya karena aspek religius mencakup sebuah keyakinan, pemikiran, dan tindakan-tindakan atau solusi yang harus diambil atau dijalani oleh tokoh dalam sebuah cerita yang berhubungan dengan nilai religius agama yang dianutnya.

Daya tarik psikologis dalam karya sastra juga menjadi hal yang sangat penting karena di dalamnya terdapat beragam ungkapan jiwa. Jiwa keinginan ini memikat peneliti melakukan spekulasi-spekulasi penafsiran. Jiwa spekulasi ini cukup menarik ini membuat satu karya sastra seperti novel Bidadari Bermata Bening. Masalah kejiwaan tokoh utama dan nilai religius dalam novel ini menarik dijadikan fokus penelitian.

Munculnya berbagai masalah memiliki nilai-nilai positif bagi tokoh utama untuk selalu mendekatkan diri dengan Allah Swt. Selain itu, karya sastra juga memberikan pesan yang luas, mendalam, dan juga kehidupan manusia yang penuh tantangan serta perjuangan. Sastra juga berisikan cerita kemanusiaan, isyarat keimanan, cinta kasih, kejujuran, dan realita. Selain itu, karya sastra juga memberikan pesan moral yang berwujud nilai religius. Cerita dan peristiwa dalam karya sastra tidak dapat dilepaskan dari aspek religius. Cerita dan peristiwa dalam karya sastra tidak semua memiliki pesan moral yang bersifat religius, pada dasarnya ajaran religius yang hendak disampaikan kepada pembaca merupakan bagian dari misi diciptakannya karya sastra. Aspek religius lebih menekankan pada kebenaran atau kesalahan, kebaikan atau keburukan dalam cerita sastra sehingga dapat 
menjadi pelajaran moral bagi pembaca. Adapun nilai religius yang terkandung dalam novel yang memiliki unsur nilai religius adalah akidah, akhlak dan Syariah.

Kajian tentang aspek religius karya sastra dapat menempatkan sastra sebagai karya seni mengandung nilai keindahan dan di samping dapat menjadi pelajaran tentang norma-norma religius kehidupan bermasyarakat. Kajian religius sastra dapat meningkatkan harkat dan martabat manusia sebagai makhluk yang berbudaya dan ciptaan Tuhan, di samping memberi nilai tambah terhadap mutu atau kualitas apresiasi sastra.

\section{METODE}

Pendekatan yang digunakan dalam penelitian ini adalah pendekatan kualitatif yang menekankan pada kutipan teks novel Bidadari Bermata Bening Karya Habiburahman El-Shirazy yang memuat aspek psikologis tokoh utama dan nilai religius dalam novel. Sumber data dalam penelitian ini adalah dokumen yakni novel Bidadari Bermata Bening Karya Habiburahman El-Shirazy. Novel ini diterbitkan oleh Republik Penerbit, memiliki 336 halaman, 17 bab. Yang diterbitkan pada tahun 2017. Teknik pengumpulan data yang digunakan dalam penelitian ini adalah observasi nonpartisan. Dalam observasi nonpartisan peneliti tidak terlibat langsung tapi hanya sebagai pengamat (Sugiyono, 2014). Instrument yang digunakan dalam penelitian ini adalah peneliti sendiri dengan bantuan tabel analisis dengan paragraf yang mengandung psikologis tokoh utama dan nilai religius dan jumlah kutipan paragraf yang mengandung kedua nilai tersebut. Hal ini bertujuan untuk mengetahui psikologis tokoh utama dan nilai religius dalam setiap kalimat tersebut.

\section{HASIL DAN PEMBAHASAN}

Penulis memaparkan hasil penelitian psikologis tokoh utama dan nilai religius pada novel Bidadari Bermata Bening Karya Habiburahman El-Shirazy. Teks tersebut dipilih penulis sebagai objek kajian karena novel ini sebagai salah satu acuan dalam khasanah sastra Indonesia. Oleh karena itu, kajian tersebut perlu dilakukan, terutama dalam unsur psikologis tokoh utama dan nilai religius. Di bawah ini merupakan hasil kajian penelitian psikologis tokoh utama dan nilai religius pada novel Bidadari Bermata Bening Karya Habiburahman El-Shirazy.

Tabel 1. Psikologis Tokoh Utama Novel Bidadari Bermata Bening Karya Habiburahman El-Shirazy

\begin{tabular}{clccc}
\hline No & & Aspek Analisis & Jumlah & Persentase \\
\hline 1 & Id & & 43 & $39 \%$ \\
2 & Ego & & 36 & $33 \%$ \\
3 & \multirow{2}{*}{ Super Ego } & & 30 & $28 \%$ \\
& & Jumlah & $\mathbf{1 0 9}$ & $\mathbf{1 0 0 \%}$ \\
\hline
\end{tabular}


Tabel 2. Nilai Religius dalam Novel Bidadari Bermata Bening Karya Habiburrahman El-Shirazy

\begin{tabular}{ccccc}
\hline No & & Aspek Analisis & Jumlah & Persentase \\
\hline 1 & Akidah & & 57 & $31 \%$ \\
2 & Akhlak & & 61 & $34 \%$ \\
3 & Syariah & & 64 & $35 \%$ \\
& & Jumlah & $\mathbf{1 8 2}$ & $\mathbf{1 0 0} \%$ \\
\hline
\end{tabular}

Berdasarkan tabel di atas, dapat diketahui bahwa dalam novel Bidadari Bermata Bening karya Habiburrahman El-Shirazy terdapat 291 informasi atau temuan dalam psikologis tokoh utama dan nilai religius. Informasi yang menunjukkan Id sebanyak 43 kutipan sebesar $39 \%$, unsur ego sebanyak 36 kutipan sebesar $33 \%$, dan unsur super ego sebanyak 30 kutipan sebesar $28 \%$. Nilai religius yang paling tinggi adalah syariah. Informasi atau temuan yang menunjukkan unsur akidah sebanyak 57 kutipan sebesar $31 \%$, unsur akhlak sebanyak 61 kutipan sebesar $34 \%$, dan unsur Syariah sebanyak 64 kutipan sebesar $35 \%$.

\section{Psikologis Tokoh Utama}

1. Id

Kalau saya lulus saya senang dan kalau saya nggak lulus juga senang, gumam Ayna. Kalau nggak lulus kan berarti ilmu saya masih kurang, itu jadi intropeksi bagi saya untuk belajar lagi. Lebih dari itu, kalau nggak lulus kan aku masih di sini bersama mbak-mbak semua yang sudah kuanggap seperti saudara sendiri." (Hlmn: 11)

Dari data di atas bahwa Ayna selalu bersyukur apa pun yang telah ia capai. Ia tidak ingin memikirkan hal-hal yang membuatnya pusing. Ayna tidak ingin mengambil pusing, sebab jika tidak lulus berarti ia merasa ilmunya masih kurang. Jika tidak lulus, berarti ia masih ditakdirkan untuk tetap tinggal dan menimba ilmu di pesantren

2. Ego

Hati Ayna terasa perih, batinya berdarah. Ayna tidak menjawab, ia menundukkan kepala dan menutup mukanya dengan kedua tangan. Ia matimatian menahan diri agar tangisannya tidak meledak saat itu. (Hlmn. 134)

Dari data di atas bahwa Ayna hanya bisa menahan perih di saat Pakde dan Budenya menolak Kyai Yusuf dengan alasan bahwa ia tidak ingin menikahkan Ayna dengan duda beranak dua. Ayna tidak bisa mengeluarkan sepatah kata pun saat itu. Ia tak kuasa menahan tangisnya, ia menangis menutup mukanya dengan kedua telapak tangannya. Ayna tidak hanya menangis kecewa karena karena lamaran niat baik Kyai Yusuf ditolak oleh Pakde dan Budenya, tetapi ia tidak ingin mengecewakan Kyai dan Bu Nyai yang punya niat baik menikahkannya dengan seorang Kyai terkenal yang punya akidah akhlak yang baik kepada Allah Swt.

3. Super ego

Belum ada satu jam yang lalu kau menghinaku sambil menghina ibuku. Kau katakan aku ini anak haram seorang TKW yang seorang di Arab, iya kan? 
Kau mengatakan begitu?" "Benar, ibuku TKW pulang dalam kondisi hamil. Tapi ibuku tidak serong. Aku bukan anak haram! Kau menghina ibuku, menuduh ibuku keji! Ini qadzaf! Aku tidak terima!”. (Hlmn. 19)

Dari data di atas, setelah Ayna bukti rekaman dari Zulfah bahwa Neneng telah memfitnah ibunya berzinah dengan majikannya di Arab, Ayna langsung memperjelas kata-kata yang ia sampaikan bahwa tidak layak Neneng yang belum tahu fakta yang terjadi langsung menuduh dan memfitnah. Ayna sangat marah dan mengatakan bahwa dia bukanlah anak haram seperti yang disampaikan oleh Neneng. Ayna sangat tidak terima hinaan dari Neneng.

Novel Bidadari Barmata Bening Karya Habiburrahman El-Shirazy layak diteliti karena mengandung unsur psikologis yang tinggi. Unsur yang dikaji dalam novel ini adalah $i d$, ego, dan super ego. Unsur psikologis yang paling menonjol pada tokoh utama dalam Novel Bidadari Barmata Bening Karya Habiburrahman El-Shirazy adalah unsur Id. Terdapat 109 informasi atau temuan dalam psikologis tokoh utama. Informasi yang menunjukkan Id sebanyak 43 kutipan sebesar $39 \%$, unsur ego sebanyak 36 kutipan sebesar 33 $\%$, dan unsur super ego sebanyak 30 kutipan sebesar $28 \%$. Unsur yang dominan yang terdapat dalam diri Ayna lebih mengarah pada kesabaran di saat menghadapi berbagai persoalan yang mengusik ketenangan hidupnya. Ayna sangat menghormati dan menghargai wasiat ibunya meski membuatnya menderita karena ia menepati janji dan kecintaan ibunya sehingga ia mengabulkan wasiat ibunya. Iya sangat patuh dan nurut. Ia tahu menjalankan wasiat ibunya sama saja seperti ia taat kepada Allah Swt.

\section{Nilai Religius}

\section{Akidah}

Ayna bertakbir dan sujud syukur di lantai dapur itu. Ayna bangkit dari sujud syukurnya dan langsung memeluk Mbak Ningrum. "Terima kasih mbak ini juga karena jasa kalian semua" (Hlmn. 13)

Dari data di atas bahwa Ayna bersyukur atas segala nikmat Allah Swt. yang dapat ia hitung salah satunya ia telah diberikan nikmat kesehatan sehingga ia bisa menyelesaikan sola-soal UN dengan sukses. Ia benar-benar bersyukur atas nilai yang ia peroleh. Tidak henti-hentinya memuji kebesaran Allah.

2. Akhlak

Ayna bekerja dengan penuh kesungguhan. Keramahan dan keanggunannya membuat memberikan pujian. Ayna bukan jenis pekerja yang menunggu perintah. Ia adalah pekerja yang kreatif dan pikirannya jalan. Dalam waktu tidak lama, ia tahu jenis-jenis kue kesukaan Bu Rosidah. Diamdiam di kamar kosnya membuat adonan kue dan dia bawa ke kantor. Begitu kue matang ia hidangkan pada Bu Rosidah, dan tamu yang datang. Ia juga bagi pada teman-teman. Tak heran kalau dirinya disayang oleh majikan dan dicintai oleh hampir semua karyawan. (Hlmn. 259)

Dari kutipan di atas bahwa Ayna adalah sosok anak yang rajin, sangat tekun ketika bekerja. Ayna anak yang cerdas, baik hati dan sangat penyayang dengan orang lebih tua darinya. Jika dengan yang lebih tua, Ayna selalu menganggap ia adalah ibunya. Ayna diam-diam mencari tahu makanan 
kesukaan Ibu Rosidah. Ayna selalu membuat makanan tersebut dan membagikan kepada pengunjung kantor dan menyiapkan khusus Ibu Rosidah. Perbuatannya membuat orang lain terkesima dan semakin menambah rasa sayang Ibu Rosidah padanya.

3. Syariah

Fathul Mu'in yang langsung dibacakan oleh Kyai Sobron. Sebagai ngaji kepada Bu Nyai Fauziyah. Pengajian yang diampu Kyai Sobron diikuti santri senior putra dan putri. Pengajian Bu Nyai dan Ustadzah khusus untuk santri putri. Dan pengajian beberapa ustadzah, khusus untuk putra. (Hlmn. 34)

Dari data di atas bahwa Kyai Sobron mengajar dan mempelajari kitab bersama istrinya dan mengajarkannya kepada sebagian senior putra di pondok pesantren. Bu Nyai Fauziyah dan beberapa ustazah yang lain juga mengkaji kitab Bersama beberapa santri putri. Mereka mengkaji kitab dengan tujuan semakin menambah ilmu dan menambah ketaatan kepada Allah SWT.

Adapun temuan nilai religius berjumlah 182 temuan yang sudah dianalisis. Informasi atau temuan yang menunjukkan unsur akidah sebanyak 57 kutipan sebesar $31 \%$, unsur akhlak sebanyak 61 kutipan sebesar $34 \%$, dan unsur Syariah sebanyak 64 kutipan sebesar $35 \%$. Nilai yang terkandung dalam diri hampir semua tokoh yang sangat memegang teguh Syariah islam. Tokoh pertama bernama Ayna sangat takut melanggar Syariah yaitu terbukti saat ia dipaksa menikah dengan laki-laki yang tidak bisa membaca Al-Quran. Ayna tidak ingin generasinya mengalir darah orang yang jauh dari ketaatan kepada sang Pencipta. Ketika keluar rumah Ayna memilih tidak akan jalan-jalan jika memakai pakaian lefis dan menampakkan aurat. Pantang Ayna melanggar peraturan Allah untuk menikah dengan laki-laki yang sangat ia cintai jika belum sah cerai dengan suaminya. Pengasuh pondok pesantren yang selalu mengkaji kitab-kitab yang disunahkan oleh Rasulullah untuk menguatkan akidah dan Syariah. Serta anak pengasuh pesantren yang bernama Gus afif tidak akan menikahi Ayna walaupun keinginan dan impian yang begitu besar menikah dengan perempuan yang sholihah merupakan perintah Allah. Sebab menikah dengan perempuan yang sudah dikhitbah itu hukumnya haram.

\section{SIMPULAN}

Berdasarkan hasil dan pembahasan, dapat disimpulkan bahwa unsur psikologis yang paling menonjol pada tokoh utama dalam Novel Bidadari Barmata Bening Karya Habiburrahman El-Shirazy adalah unsur Id, sedangkan nilai religius yang paling tinggi adalah syariah

\section{DAFTAR PUSTAKA}

Nurgiyantoro, B. (2010). Teori Pengkajian Fiksi. Yogyakarta: Gadjah Mada University Press.

Sari, M. D. (2013). Konflik dalam Novel Kembang Alangalang Karya Margareth

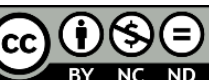

Creative Commons Attribution-NonCommercial-NoDerivatives 4.0 International License 
Diskursus: Jurnal Pendidikan Bahasa Indonesia

Vol. 2, No. 1, April 2019, pp. 28-34

p-ISSN: 2615-4935

e-ISSN: 2615-4943

Widhy Pratiwi (Doctoral Dissertation, Universitas Negeri Semarang).

Sumardjo, J., \& Saini, K.M. (1998). Apresiasi Kesusastraan. Jakarta: PT Gramedia. Sugiyono. (2014). Metode Penelitian Pendidikan: Pendekatan Kuantitatif, Kualitatif, dan R\&D. Bandung: Alfabeta 